Review article

\title{
MECHANISMS OF RESISTANCE TO QUINOLONES AND EPIDEMIOLOGICAL SIGNIFICANCE OF Salmonella spp.
}

\author{
VELHNER Maja* \\ Scientific Veterinary Institute "Novi Sad”, Rumenački put 20, Novi Sad, Serbia
}

(Received 08 February; Accepted 06 May 2016)

\begin{abstract}
Bacteria develop resistance to antimicrobial agents by a number of different mechanisms. The resistance to (fluoro)quinolones in Salmonella is of particular importance especially if therapy in humans is required. For decades there has been a significant interest in studying the biology of Salmonella because these bacteria are among the leading causes of foodborne illnesses around the globe. To this date, two main mechanisms of quinolone resistance have been established: alteration in the targets for quinolones, decreased accumulation inside bacteria due to impermeability of the membrane and/or an over expression of the efflux pump systems. Both of these mechanisms are chromosomally mediated. Furthermore, mobile elements have been described carrying the qnr gene which confers resistance to quinolones. The plasmid encoded QNR proteins belong to the pentapeptide repeat family of proteins. The plasmid mediated quinolone resistance (PMQR) is often associated with the resistance to beta lactam antibiotics. It was noticed that PMQR is backing up chromosomal mutations for quinolone resistance, hence becoming an important resistance mechanism worldwide. Even with our knowledge expanding over the years, it is not possible to predict how bacteria will respond in the future, if they are exposed to new external challenges. The possibility that they will find a way to survive by introducing new mutations or by exchanging mobile genetic elements and subsequently developing resistance to survive in the environment should not be underestimated.
\end{abstract}

Key words: salmonella, resistance, quinolones, efflux pump, PMQR

\section{INTRODUCTION}

Foodborne diseases are one of the most important concerns worldwide. The global surveillance coordinated by the World Health Organization (WHO) has documented that Salmonella Enteritidis ( $S$. Enteritidis) is a frequent cause of alimentary infections. The most prominent was the pandemic outbreak of human salmonellosis in the late 1980 caused by the consumption of table eggs. The highly prevalent Salmonellae in humans are also: Salmonella Infantis ( $S$. Infantis), Salmonella Typhi (S. Typhi) and Salmonella Montevideo (S. Montevideo). In the year 2002, Salmonella Typhimurum ( .

*Corresponding author: e-mail: maja@niv.ns.ac.rs 
Typhimurium) was most commonly isolated from nonhuman specimens, while $S$. Enteritidis was ranked in third place [1]. Even if the numbers of outbreaks caused by $S$. Enteritidis and S. Typhimurium are declining in developed countries, because of the comprehensive eradication campaign in the veterinary sector, problems regarding Salmonella infections are still very relevant.

The next growing problem is the occurrences of resistance in Salmonella, especially in cases when young children, elderly people or patients with immune deficiencies require therapy. Because treatment with antibiotics is a frequent practice in veterinary medicine, foods of animal origin present a source of infection with resistant bacteria in humans. The application of antibiotics in developed countries is restricted and more careful, comparing to the practice of antibiotic use in developing countries. However, traveling and trade impair the ecological barriers and because of that, infections with resistant bacteria are not limited only to certain areas or smaller communities [1].

Fluoroquinolones (FQ) and beta lactam antibiotics are a broad class of antibiotics, used for the therapy of humans in cases of foodborne infections. Resistance to both classes of antibiotics has been documented in the emerging multiple resistant bacteria [2]. Monitoring of the antimicrobial resistance (AMR) is supported by the National legislatives and is being authorized by International Committees, which specify annually, the recommendations for clinical and epidemiological breakpoints of target antibiotics and associated guidelines for AMR testing. The recommendations from the Clinical and Laboratory Standard Institute (CLSI) [3,4] and the European Committee on Antimicrobial Susceptibility Testing [5] are often used as interpretative criteria.

In recognition of worldwide problems of AMR, the goal of this work was to briefly summarize the research that contributed to the understanding of the major mechanism of resistance to FQ in Salmonella spp., and their epidemiological significance.

\section{Chromosomally mediated resistance to fluoroquinolones}

Resistance to FQ in Salmonella occurs due to the point mutation on genes encoding topoisomerase enzymes. These enzymes act to regulate DNA supercoiling by catalyzing the winding and unwinding of the DNA strands. Therefore topoisomerase enzymes are essential for the replication of bacteria. The GyraseA is the primary target in Gram-negative bacteria. It consists of two subunits, the GyrA and GyrB, encoded by their complementary genes ( $g y r A$ and $g y r B$ ). Topoisomerase IV is the main target in Gram-positive bacteria and a secondary target in Gram negative microorganisms. The parC and parE genes encode two subunits (ParC and ParE) of the topoisomerase IV and they are homologous to the GyrA and GyrB subunits. Mutations induced by (fluoro)quinolones occur in the Quinolone resistance determining region (QRDR). This region encompasses amino acids from Ala67-Gln106 in the gyrA and Asp426Lys447 in the gyrB [6,7]. In Salmonella the most frequent mutations are introduced on codons Ser83 and Phe87. The Ser83 $\rightarrow$ Phe substitution is favored by enrofloxacin (a fluoroqunolone antibiotic), while nalidixic acid and ciprofloxacin, induce mutations 
on codon 87 more often [8]. The increasing rate of FQ resistance is associated with the two point mutations in the gyrA gene in Salmonella. The most frequent double substitutions are Ser83 $\rightarrow$ Phe and Asp $87 \rightarrow$ Asn. Common mutations on the parC gene correspond to codons 78,80 and 84 while the most frequent mutation on the $g y r B$ and parE gene are at the codons 464 and 458 respectively. Concomitant mutations on the gyrA, gyrB, parC and parE genes in Salmonella spp, Escherichia coli (E. coli) and Campylobacter spp isolates from all around the globe have been summarized recently [9]. Particularly, double, triple and quadruplet FQ mutants in Salmonella are reported more frequently in isolates from developing countries. Hence, easy access and uncontrolled use of antibiotics in human and veterinary medicine contributes to the development of mutational polymorphism in Salmonella spp. [10]. Salmonella which are resistant to FQ usually attain a multidrug resistant phenotype (MDR), but the occurrence of such isolates in food producing animals and humans is not common.

The evidence of a clonal spread of Salmonella Typhimurium definite phage type 204 (STDT204), harboring the resistance to FQ, presents an important example of the occurrence of FQ resistant strains of Salmonella in humans and animals. Point mutations which are found in the topoisomerase genes of the STDT204, are associated with the following amino acid transitions: gyrA (Ser83 $\rightarrow$ Ala, Asp87 $\rightarrow$ Asn); gyrB Ser464 $\rightarrow$ Phe and par $C$ gene $(S e r 80 \rightarrow I l e)$. The STDT204 is also resistant to ampicillin, kanamycin, tetracycline, chloramphenicol and trimethoprim [11]. The related strain, Salmonella Typhimuirum DT104 harbors resistance to ampicillin, chloramphenicol, streptomycin, sulphonamides and tetracycline (ACSSuT, R type) and acquires a decreased susceptibility to $\mathrm{FQ}$. The Asp $87 \rightarrow$ Asn amino acid substitution is most frequently found on the gyr $A$ gene [12].

The clonal spread of multidrug resistant Salmonella Kentucky ( $S$. Kentucky) is today the most prominent example of new, well established, clones of Salmonella. The first multidrug resistant strain of $S$. Kentucky was isolated from French travelers returning from Africa, and soon after that, it was diagnosed worldwide. The emerging clones are highly resistant to ciprofloxacin but also to amoxicillin, streptomycin, spectinomycin, gentamycin, sulfametoxazole and tetracycline. Chromosomal mutations on topoismorease genes play a major role in the resistance to FQ in $S$. Kentucky. The following point mutations are responsible for this type of resistance: Ser83 $\rightarrow$ Phe and Asp87 $\rightarrow$ Asn or Tyr, Gly on the gyrA gene and Ser80 $\rightarrow$ Ile on the parC gene. Clonal strains are a multi locus sequence type 198. After the DNA digestion with the restriction enzyme $\mathrm{XbaI}$, the pulsed gel electrophoresis type is established as $\mathrm{X} 1$, [13]. Because the strains producing the extended spectrum cephalosporins (ESCs) and carbapenems were identified recently, it is important to report the occurrence of multiple resistant strains of $S$. Kentucky [14].

The emergency of quinolone resistant clones of $S$. Infantis in humans and food animals is also taking an important place in the epidemiology of Salmonella. The FQ resistance in $S$. Infanits is reported in multiple resistant strains in Hungary [15] and recently in Serbia $[16,17]$. Multiple resistance phenotypes of $S$. Infantis are also being 
recorded in Japan, Israel, Germany and Argentina [18,19,20]. Perhaps, S. Infanits has "accommodated" to the animal farms and along the food chain and is considered as a clonal strain [19]. The sharp increase in the incidence of multidrug resistant $S$. Infantis in Israel was noticed in 2007 [21]. The new strains of $S$. Infants were resistant to NAL, nitrofurantoin, tetracycline (TET) and trimethprim-sulfamethoxazole (SXT). Resistance to TET and SXT is encoded from a single-large mosaic, self-transmissible plasmid, of $280 \mathrm{~kb}$ (pESI). Resistance to NAL and nitrofurantoin is associated with chromosomal mutations. The emerging strains are also tolerant to a toxic concentration of inorganic mercury and are increasingly tolerant to hydrogen peroxide. The next very important discovery in the existing $S$. Infantis clones from Israel, is the presence of genetically related, previously uncharacterized, chaperon-usher fimbria operons, the K88-like and the Ipf fimbria, from the pESI. The presence of virulence factors, such as fimbriae, is responsible for higher pathogenicity, increased inflammation, and prominent adhesion to mammalian host cells, and for the high ability of the biofilm formation. The conjugative transfer revealed that the new plasmid is transferable to a plasmid free $S$. Infantis and E. coli, implicating the possibility of a broad dissemination of the pESI plasmid in microbiota. Successive passages in the antibiotic free medium have shown that the plasmid is stable in the absence of selective pressure. Resistance to quinolones is attributed to a single nucleotide substitution at position 259 where guanine is replaced with thymine, causing the Asp $87 \rightarrow$ Tyr transition. For the first time it was shown that an adenine-guanine substitution, resulting in a nonsense mutation at a position 159 in the nitroreductase gene $n f_{s} A$, introduces a premature stop codon and that this genetic event causes the resistance to nitrofurantoin in $S$. Infantis. The sharp increase of the FQ resistance in clinical isolates of Salmonella enterica serovar Choleresuis ( $S$. Choleresuis) was recorded in two teaching hospitals in Taiwan from the year 2001 to 2003. The hospital patients with the acquired infection from the $\mathrm{CIP}^{\mathrm{r}}$ clone of $S$. Choleresuis did not receive therapy with the fluoroquinolones before admission to the hospital. It was observed that the resistance to FQ is related to the mutations on the gyr $A$ gene, generating the following amino acid substitutions: Ser83 $\rightarrow$ Phe and Asp87 $\rightarrow$ Asn. The pork meat was identified as the source of human infection with $S$. Cholersuis in Taiwan [22].

Mutations on the topoisomerase genes do not occur suddenly, but as a consequence of the persistent use of FQ antibiotics in clinical practice or livestock production. Hence, the occurrence of antimicrobial resistance in Salmonella develops in either longer or shorter timeframe. Decreased susceptibility to CIP has to be reported in every country and consequent measures should be taken to reduce the use of antibiotics in veterinary and human medicine.

\section{The efflux mechanism of resistance to $F Q$ in Salmonella}

A very important mechanism of resistance to FQ in Salmonella is associated with the Resistance-nodulation-division (RND) family of proteinaceous transporters, localized in the cytoplasmic membrane. The most important efflux system is represented by a 
tripartite efflux pump - the AcrAB-TolC. The AcrAB-TolC efflux pump is activated as a consequence of an overexpression of the acrB gene. The transporter protein $\mathrm{Acr} B$ has the ability to extrude a number of unrelated compounds from the bacterial cells and it is responsible for the development of a multiresistant phenotype in Salmonella. The AcrB forms a tripartite complex with the periplasmic adaptor protein (PAP) and with the outer membrane channel protein TolC $[6,7]$. The efflux mechanism is driven by the proton-motive force energy. It was established that the efflux system plays a major role in the resistance to FQ but also to unrelated antibiotics in STDT204. Hence, the inactivation of the acrB gene induces the 16-32 fold decrease in the resistance to fluoroquinolones, regardless of the several mutations on the topoisomerase genes. [23]. Genetic regulation of the AcrAB-TolC relies on the repressor protein named AcrR. Thus mutations on the acrR gene have an influence on the overexpression of $\operatorname{acr} A B$. The mutations in acrR gene have been studied and it was found that a $6 \mathrm{bp}$ duplication of the nucleotides 223-228 which caused the duplication of amino acids Ile 75 and Glu 76 in quinolone resistant mutants of $S$. Typhimurum, selected in vitro, were responsible for the lower activity of the repressor protein and subsequently increased efflux pump mechanism. Complemenation experiments of laboratory derived mutants with a plasmid borne, wild type acrR gene, have shown a decreased resistance to several unrelated antibiotics. Hence, the multidrug resistance phenotype is attributed to mutations on the acrR [24]. It is interesting to note that STDT204 also activates the alternative efflux mechanism, the AcrEF, in cases when arrB gene is inactivated. The integration of the IS1 or IS10 transposable elements creates a new and stronger promoter sequence, upstream of the acrE, and consequently activates the transcription of the arrEF efflux pump[25]. At a global level, the expression of the AcrAB-TolC system is regulated by the family of AraC/XylS transcriptional activators, MarA, SoxS, Rob and RamA in Salmonella or E. coli [26]. The repressor gene ramR of the ram regulon was shown to regulate the ram $A$ gene expression in Salmonella Typhimurium strains. Several point mutations leading to amino acid exchanges, frameshift mutations or the insertion of the IS1 element within ramR have been detected experimentally in $S$. Typhimurium and have caused interruption of the repressor gene. In the STDT104 isolate, deletions of two nucleotides from the putative binding site of the RamR protein were also detected. Complementation experiments with the wild type ram $\mathrm{R}$ gene or inactivation of the $\operatorname{ram} A$ gene has shown that particular mutation is indeed involved in the MDR phenotype in S. Typhimurium [27].

$S$. Typhimurium mutants obtained in vitro were used to examine the occurrence of genetic alterations in the ram $A$ gene and soxRS region. It was found that a $9 \mathrm{bp}$ deletion in the promoter region of the ramA gene (LTL strain), probably representing the RamR binding site, has an effect on the constitutive expression of the $\operatorname{ram} A$ gene and the acr $A B$. The replacement of the wild type $\operatorname{ram} A$ allele with the mutant allele $\operatorname{ram} A^{c}$ has shown a significantly higher MICs to fluoroquinolones, chloramphenicol and tetracycline, in laboratory mutants, expressing multiple mutations on the toposiomerase genes (LTH mutant), or in LT2 isolate without chromosomal mutations on the topoisomerase 
genes. An increased soxS expression was associated with an in frame $3 \mathrm{bp}$ insertion creating two amino acid exchanges and an alanine insertion at the $\mathrm{C}$ terminus. Genetic alterations on the soxS gene were found to be associated with an in frame $12 \mathrm{bp}$ deletions as well as eight residue alterations at the $\mathrm{C}$ terminus. The deletion of thymine which has caused a frameshift mutation at the stop codon -153 , probably delaying the termination of the transcription in laboratory mutants of $S$. Typhimurium, was also found. However, the introduction of the soxRS allele from LTH to LT2 (having susceptible phenotype) did not induce changes in drug susceptibility. This means that the constitutive $\operatorname{ram} A$ transcription but not of the sox $S$, activates the MDR phenotype in $S$. Typhimuirum mutants, with or without chromosomal mutations in the QRDR [28].

Genetic alterations on the ramR gene were identified also in Salmonellae other than Typhimurium obtaining a decreased susceptibility to fluoroquinolones, tetracycline, florfenicol and chloramphenicol. After Salmonella were exposed to increased concentrations of ciprofloxacin in vitro, the following mutations in the global regulators were induced: the $\mathrm{R} 46 \mathrm{P}$ amino acid exchange in the RamR was detected in Salmonella Livingstone 3 (mutant 2), in $S$. Infantis and S. Paratyphi B 10 (mutant 2), a 10 or 15 bp deletion was found in the ramR gene, causing a generation of an early stop codon and a loss of five amino acids respectively, in Salmonella Paratyphi B10 (mutant 2) a single base pair exchange $\mathrm{GAA} \rightarrow \mathrm{GAC}$ has resulted in an amino acid exchange E160D generating a stop codon at 160. These genetic events have increased the $\operatorname{ram} A$ gene expression and minor increase in acr $A$ and tol $C$ gene expression. In Salmonella Paratyphi B5 (mutant 3), a point mutation $(C \rightarrow A)$ was found between the $\operatorname{ram} A$ gene and the repressor gene (presenting the repressor gene binding site) and this mutation has increased the $\operatorname{ram} A$ expression to a moderate level (10 fold comparing to the aforementioned alterations that induced the increase of the $\operatorname{ram} A$ gene expression of 34.3, 41.6 and 94.8 fold). For the first time an insertion of 49 bp in the soxR gene has been identified introducing an early stop codon which resulted in the up regulation of the soxS gene in Salmonella Virchow mutant 2 (strain1). This research work has shown that alterations on the $\operatorname{ram} \mathrm{R}-\operatorname{ram} A$ and the $\operatorname{sox} S$ gene can activate the efflux mechanism by an upregulaton of the AcrAB system in salmonellas other than Typhimurium [29].

In Gram-negative bacteria, the resistance-nodulation-division families of proteinaceous transporters play an important role in transferring various compounds out of the cell. In Salmonella, two global regulatory mechanisms (Ram and Sox) seem to play a major role in the efflux pump activity but also, the local mechanisms of regulation of the AcrAB and AcrEF pump are very important. Inactivation of the RND efflux systems by specific inhibitors was shown to alter the expression of virulence genes as well. Such compounds are becoming attractive targets for a new generation of antimicrobial drugs in the future [26]. 


\section{Plasmid mediated resistance to $F Q$ in Salmonella spp}

The Plasmid mediated resistance (PMQR) was first reported in clinical isolates of Klebsiella pneumonie exhibiting reduced susceptibility quinolones by Martinez-Martinez and colleagues in 1998 [30]. The plasmid borne gene was named qnrA. QnrA protein protect Gyrase (the subunits and the holoenzyme) by inhibiting the Gyraze enzyme/ DNA interactions. After initial discovery of the qnrA gene an array of qnrvariants were recognized over the years. The qnrS gene was identified by Hata and colleagues in 2005 [31] from Shigella flexneri $2 \mathrm{~b}$, which was isolated during an outbreak of food poisoning in Aici Prefecture, Japan. The qnrB gene was detected from a clinical isolate of Klebsiella pneumoniae from South of India by Jacoby and colleagues in 2006 [32]. Comparison of the qnrB gene with the qnrA and qnrS genes has shown 39.5 and $37.4 \%$ of the amino acid identity respectively. This $\mathrm{QnrB}$ protein belongs to the pentapeptide repeat family of proteins and it protects the gyraze from quinolones in a similar manner like other Qnr proteins. The qnrC gene was detected from an isolate of Proteus mirabilis 06-489, from an outpatient in China experiencing urinary tract infection. The isolate conferred a low level resistance to ciprofloxacin (MIC $0.25 \mathrm{mg} / \mathrm{L}$ ). Upstream of the $q n r C$ gene a new member of the IS 3 family of insertion sequences was discovered and therefore the $q a r C$ gene presents a mobile genetic element [33]. The qnrD gene was found by Cavaco and colleagues in 2009 [34], from Salmonella enterica serovar Kentucky and Bovismorbificans isolated from human infection in China. In transformants, obtained after the conjugation experiment, a small plasmid of an approximate size of $4.3 \mathrm{~kb}$ was identified. Cloning and sequencing of the $3.2 \mathrm{~kb}$ fragment has shown that an open reading frame $(\mathrm{ORF})$ encodes a protein of 214 amino acids and the sequence identity with other members of the qnr family was as follows: $45 \%$ of identity is with the qnrA1 gene, $65 \%$ with the qnrB1 gene and $38 \%$ of identity is with the qnrS1 gene. Integron structures or other resistance determinants were not found in those isolates.

To summarize, the Qnr-type proteins have approximately 30\% variations in their nucleotide sequences, and several amino acid differences [35]. The QNR proteins do not induce a high resistance to FQ but their respective genes are frequently detected in the ESBL producing strains and multi drug resistant Gram negative bacteria $[6,36]$.

Enzymatic drug modification is probably the most widespread plasmid encoded resistance to FQ in Gram negative bacteria. The responsible gene acc(6)-Ib-cr, encodes an aminoglycoside acetyltransferase variant, which enables the $\mathrm{N}$-acetylation of the piperazinyl amine in the molecule of the CIP, conferring the resistance to CIP and norfloxacin. This gene originates from a common aminoglycoside acetyltransferase enzyme, conferring resistance to tobramycin, amikacin and kanamycin which is associated with mobile genetic elements-the integron cassette. The aac(6)-Ib-cr variant was detected for the first time in transconjugants from clinical isolates of E. coli which were isolated during the years 2000-2001, most of which were from hospitalized patients in Shanghai China. The transconjugants exhibited MIC to CIP of $0.125-2 \mathrm{mg} / \mathrm{L}$. The amino acid substitutions $\operatorname{Trp} 102 \rightarrow \operatorname{Arg}$ and Asp179 $\rightarrow$ Tyr were found to be responsible for the acetylation of the CIP by the respective enzyme. Concomitant detection of the 
aac(6)-Ib-cr gene and the qnrA gene is identified occasionally but a strong association with these two genes or other qnr determinants is not evident. However, the presence of the aac(6)-Ib-cr gene facilitates the selection of chromosomal mutations in the presence of the FQ [37, 38, 39]. The qep $A$ gene was first described in clinical isolates of E. coli displaying a multidrug resistant phenotype to aminoglycosides, FQ, as well as to a broad spectrum of $\beta$-lactam antibiotics (except for ceftazidime and imipenem). The qepA gene encodes protein that operates as a proton antiporter efflux pump mechanism. The QepA protein resembles a high similarity to multidrug transporters from the major facilitator superfamily of transporters. It may have incorporated via the transposition mechanisms to E. coli from environmental bacteria which utilize their own mechanisms for extruding antibiotics structurally similar to FQ [40]. Recently discovered $\circ q \times A$ and $\circ q \times B$ genes, encode the multidrug transporters of the RNDfamily and are included for screening of the PMQR genes in Enterobacteriaceae [41]. It was discovered that clinical isolates of $S$. Typhimurum from China carry on a same plasmid the oqxAB and the aac(6)-Ib-cr genes, which accelerate the resistance to CIP. Namely, when both genes were extracted from the clinical isolates and electroporated into a negative $S$. Typhimuirum LT2, the fourfold increase of the resistance to CIP was obtained. The $o q x A B$ gene is associated with the IS26 element which means that this gene was excised from the plasmid pOLA52 and transferred to a different plasmid of Salmonella which harbors also the aac(6)-Ib-cr [42]. The worldwide distribution of the PMQR is well documented. Often strains highly resistant to FQ do not posses PMQR genes. However, Kehrenberg et al., 2006, [43] have found the qnrS gene in S. Infantis with an increased MIC to NAL $(512 \mathrm{mg} / \mathrm{L})$, which also indicates the necessity of PMQR identification in isolates with an increased resistance to FQ.

\section{Concluding remarks}

The research work in the field of antimicrobial resistance is constantly growing and for that reason the opportunity was taken to outline very briefly, the recent developments in molecular mechanisms of resistance to fluroquinolones and epidemiological aspects of Salmonella infections. A small review of mechanisms of resistance to FQ in Salmonella with a special concern towards the efflux pump system of resistance was presented just a while ago in Archives of Veterinary Medicine [44]. From the epidemiological standpoint, $S$. Infantis and $S$. Enteritidis are most frequently isolated from poultry flocks in southern Bačka and Srem region. Next but not so frequently isolated serovars in both counties are $S$. Typhimurium and $S$. Newport. It is interesting to note that $S$. Infantis was resistant only to NAL and TET and an unexpectedly, susceptible phenotype in $S$. Typhimurium was recorded [45]. $S$. Infantis clones isolated in poultry specimens from Serbia have a truncated Tn1721 transposon with the tet $A$ gene, which is responsible for resistance to tetracycline [46] The occurrence of multidrug resistant $S$. Kentucky isolated from one flock of turkey pullets was also evident. S. Kentucky in Serbia harbors a multidrug resistance phenotype and an increased resistance to FQ. Point mutations on chromosomal topoisomerase genes are major mechanisms of 
resistance in $S$. Infantis and $S$. Kentucky in Serbia. The preliminary investigation has shown that the efflux pump mechanisms play a role in the resistance development to FQ in $S$. Infantis but it was not confirmed in the existing collection of $S$. Kentucky isolates (from human and turkey specimens). The PMQR resistance genes were not found in $S$. Infantis from Serbia. Because of the epidemiological importance of Salmonella, especially serovars with an acquired resistance to FQ, we emphasized the need for compulsory monitoring of Salmonella spp. serovars but also for regular recording of the occurrence of $S$. Kentucky in Serbia [47].

The research on antimicrobial resistance is always challenging. One moment we think that a new drug or a combination of drugs will help in combating persistent or invasive infections caused by bacteria, and the next moment microbial communities acquire or recruit new genetic mechanisms to eliminate antibiotics out of the cell or prevent their responses. The question remains, is it possible to prevent the occurrence of multidrug resistant bacteria in the future and to predict genetic models which they will use to survive in the environment.

\section{Acknowledgment}

This work was financially supported by a grant from the Ministry of Education, Science and Technological Development, Republic of Serbia, Project number TR 31071.

\section{Authors' contributions}

MV has design the paper, selected reference for the presentation and wrote the manuscript. MV takes responsibilities for all aspects of the work and accuracy of the quoted data in the manuscript.

\section{Declaration of conflicting interests}

The author(s) declared no potential conflicts of interest with respect to the research, authorship, and/or publication of this article.

\section{REFERENCES}

1. Galanis E., Lo Fo Wong DM, Patrick ME, Binsztein N, Cieslik A, Chalermchikit T, AidaraKane A, Ellis A, Angulo FJ, Wegener HC: Web-based Surveillance and global Salmonella distribution, 2000-2002. Emerg Infect Dis 2006, 12:381-388.

2. Petty NK, Ben Zakour NL, Stanton-Cook M, Skippington E, Totsika M, Forde BM, Phan MD, Gomes Moriel D, Peters KM, Davies M, Rogers BA, Dougan G, Rodriguez-Baño J, Pascual A, Pitout JDD, Upton M, Paterson DL, Walsh TR, Schembri MA, Beatson SA.: Global dissemination of a multidrug resistant Escherichia coli clone. P Natl Acad Sci USA, 111:5694-5699, 2014. 
3. Clinical and Laboratory Standards Institute 2015: Methods for Dilution Antimicrobial Susceptibility Tests for Bacteria that Grow Aerobically; Approved Standard-Tenth Edition. CLSI document M07-A10. CLSI Wayne, PA, USA.

4. Clinical and Laboratory Standards Institute, 2015: Performance Standards for Antimicrobial Susceptibility Testing; Twenty-Fifth Informational Supplement. Clinical and Laboratory Standards Institute document M100-S25, CLSI, Wayne, PA, USA.

5. European Committee on Antimicrobial Susceptibility Testing, European Society of Clinical Microbiology and Infectious Diseases, 2016, http://www.eucast.org/

6. Hopkins KL., Davies RH, Threlfall EJ.: Mechanisms of quinolone resistance in Escherichia coli and Salmonella: recent developments. Int J Antimicrob Ag 2005, 25: 358-373

7. Giraud E, Baucheron S, Cloeckaert A: Resistance to fluoroquinolones in Salmonella: emerging mechanisms and resistance prevention strategies. Microbes and Infect 2006, 8:1937-1944.

8. Giraud E, Brisabois A, Martel JL, Chaslus-Dancla E: Comparative studies of mutations in animal isolates and experimental in vitro-and in vivo-selected mutants of Salmonella spp. suggest a counterselection of highly fluoroquinolone-resistant strains in the field. Antimicrob Agents Ch 1999, 43:2131-2137.

9. Velhner M. and Stojanović D: Mutational polymorphism in the bacterial topoisomerase genes driven by treatment with quinolones. In: Logie, C. (editor), Point Mutation 2012, 185-210. InTech, Croatia.

10. Cui S, Li J, Sun Z, Hu C, Jin S, Guo Y, Ran L, Ma Y: Ciprofloxacin-resistant Salmonella enterica serotype Typhimurium, China. Emerg Infect Dis 2008, 14: 493-495.

11. Guerra B, Malorny B, Schroeter A, Helmuth R: Multiple resistance mechanisms in fluoroquinolone-resistant Salmonella isolates from Germany. Antimicrob Agents Ch 2003, 47:2059.

12. Threlfall J E: Epidemic Salmonella Typhimurium DT 104-a truly international multiresistant clone. J Antimicrob Chemoth 2000 46:7-10.

13. Le Hello S, Hendriksen RS, Doublet B, Fisher I, Nielsen EM, Whichard JM, Bouchrif B, Fashae K, Granier SA, Jourdan-Da Silva N, Cloeckaert A, Threlfall EJ, Angulo FJ, Aarestrup FM, Wain J, Weill FX: International spread of epidemic population of Salmonella enterica serotype Kentucky ST198 resistant to ciprofloxacin. J Infect Dis 2011, 204:675-684.

14. Le Hello S, Harrois D, Bouchrif B, Sontag L, Elhani D, Guibert V. Zerouali K, Weill XF. Highly drug-resistant Salmonella enterica serotype Kentucky ST198-X1: a microbiology study. Lancet Infect Dis 2013, 13:672-679, published on line 2013a: http://dx.doi.org/10.1016/ S1473-3099(13)70141-5

15. Nógrády N, Tóth A, Kostyák A, Pászti J, Nagy B: Emergence of multidrug-resistant clones of Salmonella Infantis in broiler chickens and humans in Hungary. J Antimicrob Chemoth 2007, 60:645-648.

16. Rašeta M., Teodorović V., Bunčić O., Katić V., Branković-Lazić I., Polaček V., Vidanović D.: Antibiotic resistance and molecular studies on Salmonella enterica subspecies enterica serovar Infantis isolated in human cases and broiler carcasses. Acta Vet Beograd 2014, 64:257-267.

17. Velhner M, Kozoderović G, Grego E, Galić N, Stojanov I, Jelesić Z, and Kehrenberg C: Clonal spread of Salmonella enterica serovar Infantis in Serbia: acquisition of mutations in the topoisomerase genes $g y r A$ and $\operatorname{par} C$ leads to increased resistance to fluoroquinolones. Zoonoses and Public Hlth 2014, 61:364-370

18. Shahada F, Chuma T, Tobata T, Okamoto K, Sueyoshi M, Takase K: Molecular epidemiology of antimicrobial resistance among Salmonella enterica serovar Infanits from poultry in Kagoshima, Japan. Int J Antimicrob Ag 2006, 28:302-307. 
19. Gal-Mor O, Valinsky L, Weinberger M, Guy S, Jaffe J, Schorr YI, Raisfeld A, Agmon V, Nissan I: Multidrug-resistant Salmonella enterica serovar Infantis, Israel. Emerg Infect Dis 2010, 16:1754-1757.

20. Hauser E, Tietze E, Helmuth R, Junker E, Prager R, Schroeter A, Rabsch W, Fruth A, Toboldt A, Malrony B: Clonal dissemination of Salmonella enterica serovar Infantis in Germany. Foodborne Pathog Dis 2012, 9:352-360.

21. Aviv G, Tsyba K, Steck N, Salmon-Divon M, Cornelius A, Rahav G, Grassl GA, Gal-Mor O: A unique megaplasmid contributes to stress tolerance and pathogenicity of an emergent Salmonella enterica serovar Infantis strain. Environ Microbiol 2014, 16:977-994.

22. Chiu CH, Wu TL, Su LH, Liu JW, Chu C: Fluoroquinolone resistance in Salmonella enterica serotype Choleresuis, Taiwan, 2000-2003. Emerg Infect Dis 2004, 10:1674-1676.

23. Bucheron S, Imberechts H, Chaslus-Dancla E, Cloeckaert A: The AcrB multidrug transporter plays a major role in high level fluoroquinolone resistance in Salmonella enterica srovar Typhimurium phage type DT204. Microb Drug Resist 2002, 8: 281-289.

24. Olliver A, Vallé M, Chaslus-Dancla E, Cloeckaert A.: Role of an acrR mutation in multidrug resistance of in vitro-selected fluoroquinolone-resistant mutants of Salmonella enterica serovar Typhimurium. FEMS Microbiol Lett 2004, 238:267-272.

25. Olliver A, Vallé M, Chaslus-Dancla E, Cloeckaert A: Overexpression of multidrug efflux operon acrEF by insertonal activation with IS1 or IS10 elements in Salmonella enetrica serovar Typhimurium DT204 acrB mutants selected with fluoroquinolones. Antimicrob Agents Ch 2005, 49:289-301.

26. Blair JM, Smith HE, Ricci V, Lawler AJ, Thompson LJ, Piddock LJV: Expression of homologous RND efflux pump genes is dependent upon AcrB expression: implications for efflux and virulence inhibitor design. J Antimicrob Chemoth 2015, 70:424-431.

27. Abouzeed YM, Baucheron S, Cloeckaert A: ramR mutations involved in efflux-mediated multidrug resistance in Salmonella enterica serovar Typhimurium. Antimicrob Agents $\mathrm{Ch}$ 2008, 52:2428-2434.

28. Zheng J, Cui S, Meng J: Effect of transcriptional activators RamA and SoxS on expression of multidrug efflux pumps AcrAB and AcrEF in fluoroquinolone-resistant Salmonella Typhimurium. J Antimicrob Chemoth 2009, 63:95-102.

29. Kehrenberg C, Cloeckaert A, Klein G, Schwarz S: Decreased fluoroquinolone susceptibility in mutants of Salmonella serovars other than Typhimurium: detection of novel mutations involved in modulated expression of ram A and SoxS. J Antimicrob Chemoth 2009, 64:11751180.

30. Martínez-Martínez L, Pascual A, Jacoby GA: Quinolone resistance from a transferable plasmid. Lancet 1998, 351:797-799.

31. Hata M, Suzuki M, Matsumoto M, Takahashi M, Sato K, Ibe S, Sakae K: Cloning of a novel gene for quinolone resistance from a transfarable plasmid in Shigella flexneri $2 \mathrm{~b}$. Antimicrob Agents Ch 2005, 49:801-803.

32. Jacoby GA, Walsh KE, Mills DM, Walker VJ, Oh H, Robicsek A, Hooper DC: qnrB, another plasmid-mediated gene for quinolone resistance. Antimicrob Agents Ch 2006, 50:11781182.

33. Wang M, Guo Q, Xu X, Wang X, Ye X, Wu S, Hooper DC, Wang M: New plasmidmediated quinolone resistance gene, $q n r C$, found in a clinical isolate of Proteus mirabilis. Antimicrob Agents Ch 2009, 53:1892-1897. 
34. Cavaco LM, Hasman H, Xia S, Aarestrup FM: qnrD, a novel gene conferring transferable quinolone resistance in Salmonella enterica serovar Kentucky and Bovismorbificans strains of human origin. Antimicrob Agents Ch 2009, 53:603-608.

35. Strahilevitz J, Jacoby GA, Hooper DC, Robicsek A: Plasmid-mediated quinolone resistance: a multifaceted threat. Clin Microbiol Rev 2009, 22:664-689.

36. Velhner M, Kozoderović G, Jelesić Z, Stojanov I, Dubravka P, Jelena Petrović: Plasmid mediated resistance to quinolones in Salmonella. Arhiv Vet Med 2012, 5: 19-29.

37. Wang M, Tran JH, Jacoby GA, Zhang Y, Wang F, Hooper DC: Plasmid mediated quinolone resistance in clinical isolates of Escherichia coli from Shanghai, China. Antimicrob Agents Ch 2003, 47:2242-2248.

38. Robicsek A, Strahilevitz J., Jacoby GA, Macielag M, Abbanat D, Park CH, Bush K, Hooper DC: Fluoroquinolone-modifying enzyme: a new adaptation of a common aminoglycoside acetyltransferase. Nat Med 2006, 12:83-88.

39. Park CH, Robicsek A, Jacoby GA, Sahm D, Hooper DC: Prevalence in the United States of aac (6')-Ib-cr encoding a ciprofloxacin-modifying enzyme: Antimicorb Agents Ch 2006, 50:3953-3955.

40. Yamane K, Wachino J, Suzuki S, Arakawa Y: Plasmid-mediated qepA gene among Escherichia coli clinical isolates from Japan. Antimicrob Agents Ch 2008, 52:1564-1566.

41. Hansen LH, Sørensen SJ, Jørgensen HS, Jensen LB: The prevalence of the OqxAB multidrug efflux pump amongst olaquindox-resistant Escherichia coli in pigs. Microb Drug Resist 2005, 11:378-382.

42. Wong MH, Chan EW, Liu LZ, Chen S: PMQR genes oqxAB and acc(6')Ib-cr accelerate the development of fluoroquinolone resistance in Salmonella typhimurium. Front Microbiol 2014, 5, article 521 .

43. Kehrenberg C, Friederichs S, de Jong A, Michael GB, Schwarz S: Identification of the plasmid-borne quinolone resistance gene qnrS in Salmonella enterica serovar Infantis. J of Antimicrob Chemoth 2006, 58:18-22.

44. Arnaut M, Velhner M, Suvajdžić Lj, Milanov D, Petrović J, Kozoderović G: The role of efflux pump and other mechanisms of antimicrobial resistance to (fluoro)quinolones in epidemic isolates of Salmonella Typhimurum, Salmonella Kentucky and Salmonella Infantis. Archives Vet Med 2014, 7:71-80.

45. Velhner M, Todorović D, Pajić M, Stojanov I: Antimicrobial resistance of Salmonella spp. isolated from poultry farms in southern Bačka and Srem region, XVI International Symposium "Feed Technology", Institute of Food Technology, University of Novi Sad, Novi Sad, 28-30, 10, 2014, p 172-175.

46. Todorović D, Velhner M, Milanov D, Vidanović D, Suvajdžić Lj, Stojanov I, Krnjaić D: Characterization of tetracycline resistance of Salmonella enterica subspecies enterica serovar Infantis isolated from poultry in the northern part of Serbia. Acta Vet Beograd 2015, 65:548-556.

47. Velhner M, Kozoderović G, Jelesić Z: Antibiotic resistance to fluoroqionoles in Salmonella spp.: Recent findings in Serbia and brief overview of resistance mechanisms and molecular typing methods, Proceedings "One Health-New Challenges" First International Symposium of Veterinary Medicine, Hotel "Premier Aqua”, Vrdnik, May 21-23, 2015, 468-472. 


\title{
MEHANIZMI REZISTENCIJE NA HINOLONE I EPIDEMIOLOŠKI ZNAČAJ SALMONELLA SPP.
}

\author{
VELHNER Maja
}

Bakterije razvijaju mnogobrojne mehanizme rezistencije na antimikrobne agense. Od posebnog značaja je rezistencija na (fluoro)hinolone kod Salmonella spp. posebno u slučajevima kada je indikovana terapija kod ljudi. Decenijama postoji veliko interesovanje za izučavanjem biologije salmonela zato što su one najčešći uzročnici bolesti koje se prenose namirnicama animalnog porekla u celom svetu. Do danas su ustanovljena dva najvažnija mehanizma rezistencije odnosno, alteracije na ciljnim genima za hinolone, smanjena akumulacija koja nastaje zbog smanjene propustljivosti ćelijskog zida i/ili prekomerne ekspresije sistema efluks pumpe. Oba mehanizma su kodirana sa hromozoma. Takođe su opisani mobilni elementi na kojima se nalaze qnr geni koji uzrokuju rezistenciju na hinolone. QNR proteini pripadaju familiji proteina koji su organizovani u pentapeptidne ponovke i kodirani su sa plazmida. Rezistencija koja nastaje preko plazmida (PMQR) obično je povezana sa rezistencijom na prošireni spektar beta laktama. Takođe je ustanovljeno da PMQR, podržava mutacije na hromozomu bakterija, uzrokujući rezistenciju na hinolone, tako da spada u veoma važne mehanizme rezistencije širom sveta. Iako se tokom godina sve više saznaje o mehanizmima rezistencije, nemoguće je predvideti kako će bakterije da reaguju u budućnosti ukoliko budu izložene novim uticajima iz životine sredine. Velika je verovatnoća da će putem novih mutacija ili izmenom mobilnih genetičkih elemenata razviti rezistenciju kako bi preživele u okruženju. 